\title{
Convenience or inconvenience of requiring the unanimous consent of the co-defendants for the negotiated criminal justice mechanisms (in a restricted sense) in the Chilean criminal procedural system
}

Conveniencia o inconveniencia de exigir el consentimiento unánime de los coimputados para los mecanismos de justicia penal negociada (en sentido estricto) en el sistema procesal penal chileno

\section{Guillermo Oliver ${ }^{1}$}

Pontificia Universidad Católica de Valparaíso, Chile

guillermo.oliver@pucv.cl

https://orcid.org/0000-0003-4485-1870

\begin{abstract}
The main objective of this work is to analyze the convenience or inconvenience of requiring the unanimous consent of all the codefendants for the adoption of agreements in the criminal process (in a restricted sense). Its secondary objective is to reflect on the possibility of making a legal modification on the subject for the Chilean criminal procedural system.
\end{abstract}

KEYWORDS: plea bargaining; negotiated criminal justice; agreements in criminal proceedings; co-defendants; abbreviated procedure.

RESUMEN: Este trabajo tiene, como objetivo principal, analizar la conveniencia o inconveniencia de exigir el consentimiento unánime de todos los coimputados para la adopción de acuerdos en el proceso penal (en sentido restringido). Su objetivo secundario es reflexionar acerca de la posibilidad de efectuar una modificación legal sobre el tema para el ordenamiento procesal penal chileno.

Palabras Clave: plea bargaining; justicia penal negociada; acuerdos en el proceso penal; coimputados; procedimiento abreviado.

1 Professor and Head of the Department of Criminal Law and Criminal Procedure Law at the Law School of the Pontifical Catholic University of Valparaíso, Chile. Doctor Iuris, University of Barcelona, Spain. Master in Criminal Law and Criminal Sciences, Universities of Barcelona and Pompeu Fabra, Spain. Criminal lawyer. 
Summary: Introduction; 1 . Agreements in the criminal process and general risk for equality before the law; 2 . The individualist model and the consensual model: advantages and disadvantages; 3. Possibilities of a proposal for the Chilean legal system; Final considerations; References.

\section{INTRODUCTION}

The expressions "negotiated criminal justice" and "agreements in the criminal process" can be understood in a broad sense or in a restricted sense. In a broad sense, they are used to refer to any agreement that takes place in the criminal process, even if it does not lead to a conviction or acquittal. In a restricted sense, they are used to refer only to an agreement that leads to a sentence that convicts or acquits the defendant ${ }^{2}{ }^{3}$. In this work, such expressions are used in a restricted sense.

Since the end of the last century, for different reasons, negotiated criminal justice mechanisms, whose origin is usually seen in the plea bargaining of the United States criminal system, have proliferated in the criminal procedure laws of different countries belonging to or adhering to the continental European legal system ${ }^{4}$. Since the so-called patteggiamento emerged in Italy in the 1980s, following a recommendation from the

2 See both senses of these expressions in HERRERA GUERRERO, Mercedes. La negociación en el nuevo proceso penal. Un análisis comparado, pp. 57-69.

3 A different terminology uses ALBERGARIA, Pedro Soares de. Plea Bargaining. Aproximação à justiça negociada nos E.U.A., pp. 17-18, who points out that consensual justice (which is opposed to imposed or conflictual justice) would be the gender and that negotiated justice would be the species (which encompasses more cases than those that in this paper are called negotiated criminal justice mechanisms in a restricted sense).

4 A brief explanation about the different causes that explain this proliferation can be seen in PRADO, Geraldo. Transação penal, pp. XXVII-XXIX. Highlights the impact that the increase in crime rates has had on this, LANGER, Máximo. From legal transplants to legal translations. The globalization of plea bargaining and the Americanization thesis in criminal procedure: "The reasons vary from jurisdiction to jurisdiction, but one common reason has been increasing crime rates in most of these countries in recent years. This 
Committee of Ministers of the Council of Europe in $1987^{5}$, different forms of agreements in criminal proceedings have been recognized in different European countries, such as, for example, in France, the plaider coupable; in Germany, the Absprache; in Spain, the conformidad ${ }^{6}$, etc.

In the context of the criminal procedure reforms in Latin America that began at the end of the last century, different forms of agreements were also incorporated into the laws of various countries in this area, without much reflection ${ }^{7}{ }^{8}$, such as, for example, in Nicaragua, the acuerdos; in Colombia, the preacuerdos and negociaciones; in Peru, the terminación anticipada; in Bolivia, in some provinces of Argentina and in Chile, the procedimiento abreviado, and so on.

Regardless of the greater or lesser effect that negotiated criminal justice mechanisms can produce for decongesting any criminal procedural system, the truth is that, over time, these agreements have received various criticisms. Among other defects, they have been attributed a coercive nature ${ }^{9}$, the deficient quality of the procedural truth that is reached

situation has produced an increasing burden on their criminal procedures, requiring them to handle more criminal cases in less time than before" (p. 48).

5 Strictly speaking, the first antecedents of the patteggiamento predated that recommendation, since its first draft took place by means of a 1981 law. See CORDERO, Franco. Procedimiento penal, p. 302.

6 Strictly speaking, the conformidad is quite old in Spain and its antecedents even predate the Criminal Procedure Law of 1882 (see BARONA VILAR, Silvia. La conformidad en el proceso penal, pp. 239-244), but in the last decades, successive legal modifications have considerably expanded its scope of application.

7 Recognizes it, for the Argentine case, MAIER, Julio B. J., Prólogo, pp. II-III.

8 See a criticism of said "import" in ANITUA, Gabriel Ignacio. La importación de mecanismos consensuales del proceso estadounidense, en las reformas procesales latinoamericanas, pp. 43-65.

9 In this sense, alluding to the plea bargaining of the United States, see LANGBEIN, John H. Torture and Plea Bargaining, pp. 3-22. The greater the distance that exists between the penalties imposed after criminal negotiation and the penalties that may be applied in oral trials, the lower the degree of voluntariness and freedom of the accused to waive the trial. In this sense, see SCHÜNEMANN, Bernd. La reforma del proceso penal, pp. 107-108.

However, Máximo Langer states that in order to consider the prosecutor's offer as coercive, the existence of a large difference between the sentence applicable after negotiation and the sentence applicable at trial is not enough, 
when such agreements are adopted has been criticized ${ }^{10}$, the consequent increased risk of conviction of innocents has been also criticized ${ }^{11}$, the decrease they produce in the preventive effectiveness of penalties has been also criticized ${ }^{12}$, it has been pointed out that they represent a danger to equality before the law ${ }^{13}$, etc ${ }^{14}$.

Regarding this last criticism, this paper examines some problems that negotiated criminal justice mechanisms may have in cases of codefendants, depending on whether or not the unanimous consent of all of them is required, in order to evaluate the merits and demerits of the Chilean regulation on the point. Some of these problems could also appear in other agreements in the criminal process. But I will concentrate on the negotiated criminal justice mechanisms in a restricted sense, because in them such problems can be more intense. First of all, in this work, the danger of these agreements in criminal proceedings for equality before the law is analyzed, because this danger increases when there are co-accused. Next, the advantages and disadvantages of the two models observed in the Latin American panorama regarding the need for the consent of all co-defendants are examined ${ }^{15}$. This is the main objective

but it is also necessary for the prosecutor to alter the normal course of the process, for example, threatening to prosecute a weak case, charging with more serious offenses than those appropriate to the facts or requesting higher penalties than those that legally correspond. See LANGER, Máximo. Rethinking plea bargaining: the practice and reform of prosecutorial adjudication in American criminal procedure, pp. 231-243.

SCHÜNEMANN, Bernd. ¿Crisis del procedimiento penal? (¿Marcha triunfal del procedimiento penal americano en el mundo?), p. 299.

DUCE JULIO, Mauricio. Los procedimentos abreviados y simplificados y el riesgo de condenas erróneas en Chile: resultados de una investigación empírica, pp. 2, 4-11.

NÚÑEZ OJEDA, Raúl. Código Procesal Penal, p. 393.

RODRÍGUEZ GARCÍA, Nicolás. La justicia penal negociada. Experiencias de derecho comparado, pp. 96-97.

14 An examination of some of such criticisms can be seen in OLIVER CALDERÓN, Guillermo. Reflexiones sobre los mecanismos de justicia penal negociada en Chile, pp. 455-457.

15 The importance of comparative law for the criminal process of Latin American countries is highlighted by STIPPEL, Jörg and MARCHISIO, Adrián. Principio de oportunidad y salidas alternativas al juicio oral en América Latina, pp. 21-22. In any case, this work is not intended to conduct a comparative law 
of the paper. As a secondary objective, the possibilities of a proposal of modification on the point are examined below for the Chilean criminal procedural system, based on the analysis of the defects and virtues of such models and on certain statistical data. The paper closes with some final conclusions.

\section{Agreements in the CRIMinal process and general Risk for EQUALITY BEFORE THE LAW}

As I have anticipated, one of the various criticisms that have been raised against negotiated criminal justice systems consists of the attack that their application may imply on the principle of equality. The basis for this criticism is found in the arbitrariness with which the prosecutor can decide to negotiate with one defendant and not with another, despite the fact that both may find themselves in an identical situation and there are no reasons for a different punitive treatment ${ }^{16}$.

Several factors can contribute to the fact that agreements in the criminal process constitute a danger to equality before the law, factors that depend on how the mechanisms of negotiated criminal justice are regulated in the different criminal procedure legislations. For example, if the conclusion of such agreements depends on the will of the prosecutor and not on an objective element, such as the penalty with which the law punishes the crime, a risk to equality may arise. The same can happen if the prosecutor is not obliged to provide reasons for not offering a

research. The references made to different laws are only intended to recognize those models.

16 In this sense it can be seen RODRÍGUEZ GARCÍA, Nicolás. La justicia penal negociada. Experiencias de derecho comparado, pp. 96-97; CABEZUDO RODRÍGUEZ, Nicolás. El Ministerio Público y la justicia negociada en los Estados Unidos de Norteamérica, pp. 272-273; DA SILVA BRANDALISE, Rodrigo. Justiça Penal Negociada. Negociação de sentença criminal e princípios processuais relevantes, p. 194; GIACOMOLLI, Nereu, José. Legalidad, oportunidad y consenso en el proceso penal, pp. 123-131. In a similar sense, but referring in general to the manifestations of the principle of opportunity, see OLAIZOLA NOGALES, Inés. El principio de oportunidad. ¿Modernización o crisis del Derecho penal?, p. 29. 
settlement to a defendant, nor is there a legal need to judicially control his decision not to do $\mathrm{so}^{17}$.

This is one of the reasons why the main mechanism of criminal justice negotiated in Chile has been criticized by a sector of the doctrine of that country ${ }^{18}$ (although this is not the aspect that has been criticized the most). In addition to the necessary consent of the defendant, the Chilean procedimiento abreviado requires the will of the prosecutor, so if he does not agree, it cannot take place. Likewise, its application does not depend on what is the penalty with which the law punishes the crime, but on what is the specific penalty that the prosecutor asks for in his accusation ${ }^{19}$.

This criticism loses some force when it comes to another Chilean mechanism of negotiated criminal justice: the admisión de responsabilidad en el procedimiento simplificado. This is so, because in this case it is the law that establishes a mandatory procedure that consists of the court asking the accused if he admits responsibility. In other words, the waiver of the trial by the accused does not depend on the will of the prosecutor ${ }^{20}$. However, since the procedimento simplificado depends on the penalty requested by the prosecutor and not on an objective criterion, the danger to equality before the law remains ${ }^{21}$.

17 See BIBAS, Stephanos. Designing plea bargaining from the ground up: accuracy and fairness without trials as backstops, p. 1069: "allowing appeals of prosecutors ' charging and plea-bargaining decisions can force them to justify their offers".

18 DEL RÍO FERRETTI, Carlos. Proceso penal, consenso de las partes y enjuiciamiento jurisdiccional, pp. 31-32; PECCHI CROCE, Carlos. El procedimiento abreviado en el nuevo Código Procesal Penal, p. 133.

19 See RODRÍGUEZ VEGA, Manuel. Discrecionalidad del Ministerio Público y objeto del juicio abreviado, pp. 517-519, who points out that this risk can be controlled with a standardization of criteria through general instructions issued by the Public Ministry. Among other general instructions of the National Prosecutor of the Public Ministry, see instructions $\mathrm{N}^{\circ} 286 / 2010$, of May 31, 2010, and $\mathrm{N}^{\circ}$ 402/2016, of July 5, 2016.

20 OLIVER CALDERÓN, Guillermo. Reflexiones sobre los mecanismos de justicia penal negociada en Chile, p. 468.

21 See the general instruction of the National Prosecutor of the Public Ministry, No. 286/2010, of May 31, 2010, in which it is stated that the application of the procedimento simplificado depends on the decision of the prosecutor (p. 3 ). 
Eventually, in order to ward off this danger to equality before the law, the advisability of dispensing with the requirement of having the will of the prosecutor for the accused to waive the trial could be evaluated, demanding only some objective requirements and the will of the defendant. Something like this happened with a reform to the Italian giudizzio abbreviato in 1999, a legal modification from which the authentic negotiation characteristic of this procedure has been questioned, precisely because of the disregard of the will of the prosecutor ${ }^{22}$.

In any case, it is evident that the risks that the use of negotiated criminal justice mechanisms produce for equality before the law are increased when it comes to co-defendants ${ }^{23}$, since in these cases it is more likely that the two or more people who are persecuted for the same crime they are in the same situation and, therefore, deserve the same punitive treatment ${ }^{24}$. The confrontation of these risks is different depending on whether the criminal procedural legislation in question is based on an individualist model or on a consensual mode ${ }^{25}$.

\section{THE INDIVIDUALIST MODEL AND THE CONSENSUAL MODEL: ADVANTAGES AND DISADVANTAGES}

In criminal procedural legislations that follow the individualist or particularist model, the possibility that agreements are adopted with only one of several co-defendants is allowed. This is the case, for example, of Ecuador, whose Code of Criminal Procedure, alluding to the procedimiento abreviado`s rules, indicates that "the existence of co-prosecuted persons

22 In this sense, DEL RÍO FERRETTI, Carlos. Proceso penal, consenso de las partes y enjuiciamiento jurisdiccional, pp. 22-23, 76, 193-195.

23 Suggest it ALBERGARIA, Pedro Soares de. Plea Bargaining. Aproximação à justiça negociada nos E.U.A., p. 122.

24 Therefore, the American Bar Association, in its Criminal Justice Standards, points out the following: "Similarly situated defendants should be afforded equal plea agreement opportunities" (standard 14-3.1(d)).

25 I have taken this way of naming the models that are described below in this work, from RIVERA LEÓN, Mauro Arturo. Algunas consideraciones sobre el procedimiento abreviado, p. 48. 
does not prevent the application of these rules to any of them" ${ }^{26}$ (art. 369). Similar provisions, all referring to the procedimiento abreviado or proceso abreviado, are found in the Codes of Criminal Procedure of, among other countries, Bolivia (art. 373), Uruguay (art. 272), Paraguay (art. 420), Costa Rica (art. 373), Guatemala (art. 464), El Salvador (art. 417), Dominican Republic (art. 363) and Mexico (art. 207), as in the new Argentine Federal Criminal Procedure Code (art. 323), all of which, in general, emulate the Model Criminal Procedure Code for Latin America (art. 371). This is also the case of Chile, in whose Criminal Procedure Code it is stated that "the existence of several accused or the attribution of several crimes to the same accused will not prevent the application of the abbreviated procedure rules to those accused or crimes with respect to which the assumptions indicated in this article concur"27 (art. 406).

On the other hand, in the legislations that are based on the socalled consensual model, when there are co-defendants, all of them must consent to the conclusion of the agreement for it to take place. For example, the still in force Code of Criminal Procedure of the Argentine Nation is based on this model, which establishes that "when there are several defendants in the case, the abbreviated trial can only be applied if all of them agree" 28 (art. 431 bis $\mathrm{N}^{\circ} 8$ ). A similar provision is found in the Criminal Procedure Code of Peru, regarding the terminación anticipada (art. 469) ${ }^{29}$.

There are also some legislations which do not make any reference to what happens when there are co-defendants, so they can hardly be qualified as representative of either of the two models. This is what happens, for example, in the Criminal Procedure Code of the Argentine Province of Córdoba (art. 415).

Both the individualist and the consensual models have virtues and defects. Among the advantages of the individualist model, it is worth mentioning the fact that it is better adjusted to the considerations

26 Free translation.

27 Free translation.

28 Free translation.

29 However, a similar institution contained in the same Code, the conclusion anticipada del juicio, is based on the individualist model (art. 372.4). 
that explain the emergence of negotiated criminal justice mechanisms. It is often stated that the proliferation of these mechanisms has been due to the need to seek efficiency in the use of the always scarce resources of the criminal procedural system ${ }^{30}{ }^{31}$, an efficiency that is also projected in saving time and resources for the accused and for the victim ${ }^{32}$. The particularist model is more efficient than the consensual one, since it allows that, at least with respect to some of the co-defendants -those who accept the agreement and renounce the trial-, there is a saving of time and resources, along with facilitate the prosecutor to reduce the complexity -given by the number of codefendants- of the causes that he takes to trial. The consensual model, on the other hand, by requiring the consent of all the co-defendants, could make it difficult to adopt agreements in criminal matters, which could lead to fewer cases ending up through negotiation and more cases having to be brought to trial, with the risk that this would have for the efficiency of the system.

However, the individualist model also has disadvantages. Among them is the obvious risk it has to equality before the law. If the consent of all the co-defendants is not necessary for the negotiation to succeed, there is a danger that only some of them will be "chosen" by the prosecutor to offer

30 Very clearly, PUENTE SEGURA, Leopoldo. La conformidad en el proceso penal español: "En suma, desde esta perspectiva práctica se reconoce simplemente, sin esfuerzo de construcción conceptual alguna que pretenda justificarlo, que la introducción de este tipo de fórmulas aplicadas al proceso penal no tiene otra finalidad que la descongestión de la maltrecha administración de justicia, cuya relativa ineficacia es particularmente insoportable en el ámbito del orden jurisdiccional penal" (pp. 31-32).

31 See VASCONCELLOS, Vinicius Gomes de. As tendências de expansão da justiça criminal negocial em âmbito internacional: a barganha como instituto importado em convergências entre sistemas, p. 162; THE SAME. Barganha e justiça criminal negocial. Análise das tendencias de expansão dos espaços de consenso no proceso penal brasileiro, pp. 150-159. This author considers that this reason does not allow to legitimize the proliferation of such mechanisms. In the same sense, see GROSSI, Ana Claudia. Pode o acordo ser uma solução para os problemas da morosidade e sobrecarga da Justiça? Subsídios para um debate, a partir da experiência alemã, pp. 133-171.

32 RIEGO RAMÍREZ, Cristián. El procedimiento abreviado, p. 208; MARTÍNEZ, Santiago. La víctima y el juicio abreviado, pp. 55-56. 
them a settlement, despite the fact that they are all in the same situation ${ }^{33}$. From this point of view, the consensual model is more respectful of the principle of equality.

Another disadvantage of the individualist model is that it allows apparently contradictory sentences to be produced, since the co-defendant who accepts the agreement and waives the trial will most likely be convicted, but the co-defendant who participated in the same crime and who is brought to trial could eventually be acquitted ${ }^{34}$. This is something that could be difficult for society to understand or accept. In the consensual model this situation is avoided, which can be considered an advantage of this model ${ }^{35}$.

On the other hand, the particularist model allows a series of risky situations to occur for the presumption of innocence of the codefendants who are not "chosen" to enter into the agreement with the prosecutor and who are taken by the prosecutor to the trial. For example, (a) the sentence that condemns those who entered into the agreement, could identify the other co-defendants as participants in the crime, even though they did not intervene in the negotiation procedure. It could also happen (b) that in the trial against the co-defendants who were not part of the agreement, the prosecutor offers as evidence the conviction obtained, and that the court bases the new conviction on that sentence. Or, (c) it could happen that in the trial against those who did not enter into the agreement, the prosecutor offers as witnesses those defendants who were convicted after the negotiation, although it is debatable that

33 In Chile, however, and despite the fact that equality before the law is recognized in the Constitution (art. 19 No. 2), the Constitutional Court has held that this characteristic of the procedimiento abreviado does not necessarily mean unconstitutionality, provided that the exercise of the prosecutor's discretionary power is not arbitrary. See judgment of May 10, 2011, case No. 1481-2009.

34 See RIED UNDURRAGA, Ignacio. El efecto de la sentencia condenatoria del procedimiento abreviado en el juicio indemnizatorio por responsabilidad civil ex delicto, p. 615, who points out that this may give rise to a paradoxically arbitrary situation.

35 LASCURAÍN SÁNCHEZ, Juan Antonio and GASCÓN INCHAUSTI, Fernando. ¿Por qué se conforman los inocentes?, p. 9; LOZANO EIROA, Marta. Conformidad y pluralidad de acusados, p. 349. 
they are true witnesses, since they would not testify on a foreign fact, but on an own fact ${ }^{36}{ }^{37}$.

These problems are not only theoretical, as they are observed in the practice of those criminal procedure systems based on the individualist model. Some of these problems have even come to the attention of international human rights courts, not the Inter-American Court of Human Rights, but the European Court of Human Rights.

In the case Navalny and Ofitserov versus Russia ${ }^{38}$ (2016), the applicants, who were co-defendants, alleged that their right to the presumption of innocence was violated and the European Convention on Human Rights was also violated, because in their opinion the national court convicted them on the basis for the conviction of another codefendant who had been convicted of the same crime after the adoption of an agreement with the prosecutor.

In relation to the first problem (a), the Strasbourg Court held that in the drafting of judicial decisions one must be especially careful not to incur a prejudice on the guilt of third parties who do not intervene in the same procedure (paragraph 99). And the Court added that, if, due to the nature of the charges, it is practically unavoidable to involve third parties in the procedure, this would have to constitute a serious impediment to a separate trial of the co-defendants (paragraph 104).

36 Affirms that they would state as defendants, MIRANDA ESTRAMPES, Manuel. La mínima actividad probatoria en el proceso penal, pp. 206-208. Claim that they would be true witnesses, DE DIEGO DÍEZ, Luis-Alfredo. La conformidad del acusado, pp. 358-359; DÍAZ PITA, María Paula. Conformidad, reconocimiento de hechos y pluralidad de imputados en el procedimiento abreviado, pp. 115-123.

37 As a demonstration of the difficulty of affirming that these cases are witnesses, it should be noted that, in Italy's Codice di Procedura Penale, there is an intermediate figure applicable in these cases: the defendant in a related proceeding or in a crime related (art. 210). He is similar to the witness, because he is required to appear in court. But he also resembles the accused, insofar as he is guaranteed that he is assisted by a defense attorney and the court advises him that he has the power not to answer the questions that are asked of him.

38 In Russia, the criminal process follows the individualist model for negotiated criminal justice mechanisms. 
Regarding the second problem (b), the European Court pointed out that, in the judgment of the applicants, the facts that founded the conviction of the co-defendant who accepted the agreement could not have been taken as proven, adding that such facts, because evidence had not been provided to prove them, they were not really proven, but legally assumed in the negotiation (paragraph 105).

Regarding the third problem (c), the Court affirmed that the codefendant who had been convicted after an agreement with the prosecutor, when testifying as a witness in the trial against the applicants, was forced to repeat the statements he had made previously, those that did not refer to truly proven facts, without their assertions being corroborated with other evidence in the trial, so that the facts could not be considered proven (paragraph 109).

The requirement that there be evidence to corroborate the statements of a co-defendant who testifies as a witness in court and who has previously been convicted through a negotiated criminal justice mechanism, was again formulated by the Strasbourg Court in the case Razvozzhayev versus Russia and Ukraine and Udalstov versus Russia (2019).

In any case, for the European Court, the simple fact that co-defendants convicted after an agreement with the prosecutor testify as witnesses in the trial against other co-defendants, does not per se represent a violation of the European Convention on Human Rights, provided that their statements are confronted and are consistent with additional evidence rendered at trial. This was argued in the case Kadagishvili versus Georgia ${ }^{39}$ (2020).

The Chilean Supreme Court also does not see problems when codefendants already convicted testify in court as witnesses against other co-defendants for the same crime ${ }^{40}{ }_{-4}^{41}$. This is so, despite the fact that, according to the Criminal Procedure Code of that country, the status of the accused is not lost until the execution of the sentence is finished (art. $\left.7^{\circ}\right)$. As long as the execution of the sentence that condemns him after

39 As in Russia, the criminal process in Giorgia follows the individualist model.

40 See its judgment of July 12, 2010, in case No. 3003-2010.

41 The possibility of this happening is favored by Article 185 of the Chilean Criminal Procedure Code, which allows the Public Ministry to separate criminal investigations without any limitation. 
the negotiation is not completed, the co-defendant maintains his right to remain silent, so he cannot be forced to testify in court as a witness for the same act against another co-defendant ${ }^{42}$.

Regardless of whether the European Court of Human Rights and the Chilean Supreme Court do not consider these situations problematic, the existence of these inconveniences could be considered another disadvantage of the individualist model ${ }^{43}$. The consensual model, on the other hand, does not provide fuel for the emergence of this kind of problems.

However, the consensual model also has drawbacks, in addition to the limited contribution it makes to the efficiency of the criminal procedure system, as noted above. On the one hand, by requiring the unanimous consent of all the co-defendants for the agreement to be concluded, it produces the inconvenience that the refusal of just one of them may prevent the others from enjoying the benefits that the negotiation can bring them. On the other hand, given the refusal of only one of the various co-defendants, the need to obtain unanimity for the negotiation to prosper could lead to all kinds of pressure against him to convince him to end up accepting ${ }^{44}$. Furthermore, the consensual model obliges not to take into account differences that could exist between the co-defendants, such as the fact that some are repeat offenders and others have never been convicted, differences that could justify a different punitive treatment.

\section{Possibilities of a proposal for the Chilean legal system}

The analysis carried out above shows that both the individualist and the consensual models have disadvantages. Indeed, and recapitulating, the particularist model has the defect that it can violate equality before the law, can give rise to contradictory sentences and can give rise to risky situations for the right to presumption of innocence of the co-defendants

${ }^{42}$ In this sense, HERMOSILLA IRIARTE, Francisco. Valoración de las declaraciones de acusados y coimputados, pp. 275-277. Against this view, see HORVITZ LENNON, María Inés. Derecho Procesal Penal Chileno, pp. 316-318, 526.

43 This is how consider it LOARCA, Carlos and BERTELOTTI, Mariano. El procedimiento abreviado en Guatemala, pp. 425-426.

${ }^{44}$ LASCURAÍN SÁNCHEZ, Juan Antonio and GASCÓN INCHAUSTI, Fernando. ¿Por qué se conforman los inocentes?, p. 9. 
who do not participate in the negotiation with the prosecutor and are taken by him to the trial. The consensual model presents the problem that it contributes less to introduce efficiency in the system, can give rise to situations of undue pressure from some co-accused to others, with the aim that all end up consenting to the agreement offered by the prosecutor, and obliges not to take into account differences that could exist between the co-defendants and that could justify a different treatment.

Of course, if a decision were made to substitute in Chile the individualist model for a consensual one ${ }^{45}$, it would be necessary to demand the agreement of all the co-defendants regarding the same fact that is attributed to them. It would be meaningless to require that two or more people who have been accused of participating in different crimes, in order to negotiate with the prosecutor, must all agree, just because the prosecutor has decided to include them in the same accusation because he considers that they have some connection between them ${ }^{46}$. From this point of view, it seems a good example to imitate that of the Criminal Procedure Code of Peru, in which article 469, regarding the terminación anticipada, after stating that "in the processes for plurality of punishable acts or of the accused, the agreement of all the accused will be required and for all the charges incriminating each one", it is indicated that, "nevertheless, the Judge may approve partial agreements if the lack of agreement refers to related crimes and in relation to the other defendants, unless this damages the investigation or if the accumulation is indispensable" ${ }^{47}$.

In any case, in order to decide to keep the individualist model in Chile or to replace it with a consensual model, first of all, perhaps it would be necessary to have in view some characteristics of practical operation of the criminal procedure system in this country.

45 In Chile, suggests adopting the consensual model, RIED UNDURRAGA, Ignacio. El efecto de la sentencia condenatoria del procedimiento abreviado en el juicio indemnizatorio por responsabilidad civil ex delicto, p. 618.

46 In a similar sense, see DE DIEGO DÍEZ, Luis-Alfredo. La conformidad del acusado, pp. 340-343, who, alluding to the conformidad in Spain, a negotiated criminal justice mechanism based on the consensual model, affirms that it is appropriate to dispense with the requirement for the consent of all co-accused when those who do not consent to the agreement are charged with crimes related. Very similar, LOZANO EIROA, Marta. Conformidad y pluralidad de acusados, pp. 353-357.

47 Free translation. 
In Chilean practice, although according the law the judge must verify that whoever accepts the procedimiento abreviado and resigns from the trial "has not been subjected to coercion or undue pressure" (art. 409 Criminal Procedure Code $)^{48}$, the judicial control of the voluntary nature of the waiver of the trial has been not too rigorous ${ }^{49}$, and it's really hard to imagine that this will chang $\mathrm{e}^{50}$. This should be considered if the consensual model is to be adopted in this country, because the possible pressure that some co-defendants could exert against others to convince them to accept the agreement offered by the prosecutor, could hardly be noticed and avoided by the judge.

On the other hand, it would be necessary to consult statistics on the mechanisms of negotiated criminal justice in Chile, for which it is useful to review the following table.

\begin{tabular}{|c|c|c|c|c|}
\hline Procedure & $\mathbf{2 0 1 7}$ & $\mathbf{2 0 1 8}$ & $\mathbf{2 0 1 9}$ & $\mathbf{2 0 2 0}$ \\
\hline $\begin{array}{c}\text { Abreviado } \\
\text { (abbreviated) }\end{array}$ & $\begin{array}{c}35.817 \\
(16,34 \%)\end{array}$ & $\begin{array}{c}37.707 \\
(17,14 \%)\end{array}$ & $\begin{array}{c}43.129 \\
(19,61 \%)\end{array}$ & $\begin{array}{c}32.140 \\
(8,89 \%)\end{array}$ \\
\hline $\begin{array}{c}\text { Simplificado } \\
\text { (simplified) }\end{array}$ & $\begin{array}{c}96.706 \\
(44,13 \%)\end{array}$ & $\begin{array}{c}96.651 \\
(43,94 \%)\end{array}$ & $\begin{array}{c}90.257 \\
(41,03 \%)\end{array}$ & $\begin{array}{c}40.106 \\
(11,09 \%)\end{array}$ \\
\hline $\begin{array}{c}\text { Monitorio } \\
\text { (penal order) }\end{array}$ & $\begin{array}{c}75.527 \\
(34,47 \%)\end{array}$ & $\begin{array}{c}75.267 \\
(34,22 \%)\end{array}$ & $\begin{array}{c}76.903 \\
(34,96 \%)\end{array}$ & $\begin{array}{c}285.477 \\
(78,96 \%)\end{array}$ \\
\hline $\begin{array}{c}\text { Juicio oral } \\
\text { (oral trial) }\end{array}$ & $\begin{array}{c}11.049 \\
(5,04 \%)\end{array}$ & $\begin{array}{c}10.305 \\
(4,70 \%)\end{array}$ & $\begin{array}{c}9.661 \\
(4,39 \%)\end{array}$ & $\begin{array}{c}3.816 \\
(1,05 \%)\end{array}$ \\
\hline Total & 219.099 & 219.930 & 219.950 & 361.539 \\
$(100 \%)$ & $(100 \%)$ & $(100 \%)$ & $(100 \%)$ \\
\hline
\end{tabular}

TABLE. Number and percentages of cases terminated in Chile by final judgment, according to type of procedure, in 2017-202051

48 Free translation.

49 This is verified by ZAGMUTT VENEGAS, Valentina. Procedimiento abreviado y simplificado en la práctica de audiencias chilenas. ¿Alguna vinculación con la condena de inocentes?, pp. 115-121; DUCE JULIO, Mauricio. Los procedimentos abreviados y simplificados y el riesgo de condenas erróneas en Chile: resultados de una investigación empírica, pp. 29-31.

50 In any case, this does not seem to be a problem that exists only in Chile. Also in the United States of America the control of the willfulness of the guilty pleas is superficial. See LANGER, Máximo. Rethinking plea bargaining: the practice and reform of prosecutorial adjudication in American criminal procedure, p. 249.

51 In this table, the information on oral trials has been extracted from the Annual Statistical Bulletins of the Public Ministry, available on the website of said institution (www.fiscaliadechile.cl). The data on abbreviated, simplified 
Compared to the North American plea bargaining, whose efficiency in the US system has been and is increasingly higher -according to Alschuler, $90 \%$ of the cases that ended with a sentence ended through said agreement ${ }^{52}$; subsequently, Devers pointed out that this occurs in 90-95\% of cases $^{53}$; and more recently, Mallord has argued that this occurs in $95 \%$ of cases $^{54}$ and Dervan and Edkins have stated that this occurs in $97 \%$ of the convictions in the federal system ${ }^{55}$-, the rate of application of the Chilean procedimiento abreviado corresponds to a much lower percentage of all cases that end with a sentence. After the gradual entry into force of the new criminal process in some regions of Chile in 2000, the procedimiento abreviado was applied in an even lower percentage of cases, but when the new system was already in force throughout the country in 2005, as a consequence of certain legal modifications that allowed to advance the procedural moment from which this procedure can be requested, its application experienced an increase, reaching up to $16-17 \%$ of the cases finalized by sentence, its application remaining stable around to this figure since then ${ }^{56}$, reaching $19 \%$ in $2019^{57}$.

In any case, the function of issuing sentences (generally convictions) without reaching a trial in Chile is not exclusive to the procedimiento abreviado, but is shared with the procedimiento monitorio, a type of procedure by criminal order (art. 392 Criminal Procedure Code), and also with the procedimiento simplificado when, as occurs in the great majority of cases in this procedure, it operates as a negotiated criminal justice mechanism and the accused admits responsibility (art. 395 Criminal

and penal order procedures has been provided by the Regional Prosecutor's Office of the Public Ministry of Valparaíso.

52 ALSCHULER, Albert W. Plea bargaining and its history, p. 1.

53 DEVERS, Lindsey. Plea and Charge Bargaining. Research summary, pp. 1 y 3.

54 MALLORD, Joel. Putting plea bargaining on the record, p. 688.

55 DERVAN, Lucian and EDKINS, Vanessa. The innocent defendant's dilemma: an innovative empirical study of plea bargaining's innocence problem, p. 7.

56 OLIVER CALDERÓN, Guillermo. Reflexiones sobre los mecanismos de justicia penal negociada en Chile, pp. 457-458.

57 The drop to $8 \%$ in 2020 is explained by the suspension of many hearings, due to the current pandemic situation, and by a radical increase in the procedimento monitorio (penal order procedure), due to its massive use in violations of health regulations issued to face the pandemic. 
Procedure Code $)^{58}$. If the table that appears above is observed, it can be verified that the joint consideration of the procedimiento abreviado, the procedimiento monitorio and the procedimiento simplificado corresponds to approximately $95 \%$ of the cases that end with a sentence.

A recent empirical research led by Langer shows that, in Chile, the "rate of administratization of criminal convictions", that is, the percentage of total sentences handed down that are obtained without an oral trial, corresponds to $91 \%{ }^{59}$. According to this research, the United States rate is $98 \%$. As can be seen, both figures are not far from each other.

These considerations would allow questioning the correctness of proposing the substitution in Chile of the individualist model for the consensual one. The fact that, in a global vision of the Chilean mechanisms of negotiated criminal justice, the procedimiento abreviado and the procedimiento simplificado con admisión de responsabilidad seem to contribute greatly to the efficiency of the system, could suggest the inconvenience of restricting their operation by requiring, when there are co-defendants, that everyone agree with that procedures. At least, such inconvenience would exist as long as there is no statistical information available about the number of criminal cases in which there are co-defendants.

In addition, as can be seen in the table above, between 2017 and 2019, the application of the procedimiento abreviado has increased and the number of oral trials has decreased. This could be due to Law No. 20,931, of 2016, which increased the severity of the penalties for thefts and robberies, crimes that account for around 40 percent of crime in Chile ${ }^{60}$. By virtue of this legal modification, in many cases, the only possibility that the convicted defendant does not go to jail is that he has

58 According to DUCE JULIO, Mauricio. Los procedimentos abreviados y simplificados y el riesgo de condenas erróneas en Chile: resultados de una investigación empírica, p. 16, between the years 2005 and 2016, the admission of responsibility was present, on average, in $98.66 \%$ of the procedimientos simplificados.

59 LANGER, Máximo. Plea bargaining, conviction without trial and the global administratization of criminal convictions, p. 21.

60 OLIVER CALDERÓN, Guillermo. Reflexiones sobre los mecanismos de justicia penal negociada en Chile, p. 462. 
waived the trial and has accepted a procedimiento abreviado ${ }^{61}$. This could also make it inconvenient to adopt the consensual model in this country.

In any case, an opposition to replacing the individualist model with the consensual one, in view of the greater efficiency of that one over this one, it could not mean an extreme defense of said model. In other words, if a decision were made to maintain the particularist model so as not to reduce the efficiency of the system, the disadvantages that are usually attributed to it should be taken into account, introducing some modifications that tend to avoid its main defects.

For example, in order to avoid the risk of situations of violation of the presumption of innocence of those co-defendants who are not part of the agreement and are brought by the prosecutor to trial, it would be convenient to incorporate some provision that would protect them from possible prejudices, both in the procedimiento abreviado and in the procedimiento simplificado's regulation. In this sense, a good example to follow is the Code of Criminal Procedure of Honduras, according to which, "when there are several defendants, the acceptance of the abbreviated procedure by any of them will not be extended to the others nor will it prejudge their guilt" (art. 403) ${ }^{62}$.

For the same purpose, it would be convenient to incorporate in the regulation of both Chilean negotiated criminal justice mechanisms, some precept that prevents in the trial against those co-defendants who did not sign the agreement with the prosecutor, from offering the conviction obtained after negotiation with the other co-defendants as evidence. In this sense, it is a good example to emulate that of the Uruguayan Code of Criminal Procedure, which, referring to the procedimiento abreviado`s rules, after stating that "the existence of several defendants will not prevent the application of these rules to some of them", it adds that "in

61 See RIEGO RAMÍREZ, Cristián. El procedimiento abreviado en la ley 20.931, pp. 1097-1098. This author, in 2017, predicted that Law No. 20,931 would lead to an increase in the application of the procedimiento abreviado and to a decrease in the number of oral trials. In the same sense, see RIEGO RAMÍREZ, Cristián. La renuncia a las garantías del juicio oral por medio del procedimiento abreviado en Chile, pp. 842-843.

62 Free translation. 
that case, the agreement entered into with one defendant may not be used as evidence against the rest" (art. 272) ${ }^{63}$.

Regarding the risk that the individualist model produces for equality before the law, this danger could be controlled if a duty of the prosecutor was established in the Chilean regulation of both agreements to explain to the judge, when approving the agreement that is submitted for his consideration, the reasons why the prosecutor has offered it to some co-defendants and not to others who have also requested it. In this way, the risk of arbitrariness would be reduced. Something similar, although it is not exclusively applicable to the cases of co-defendants, happens in the Italian Codice di Procedura Penale regarding the patteggiamento. It is established there that the accused can request the application of this instrument and that "il pubblico ministero, in caso di dissenso, deve, enunciarne le ragioni" (art. 446.6). If the judge considers the reasons unfounded, the decision must be adopted in the terms demanded by the accused $^{64}$.

Finally, the possibility that, in an individualist model, the codefendants who negotiate with the prosecutor are convicted and that, on the other hand, those who participated in the same crime, but do not negotiate and are brought to trial, are acquitted, will always exist; it is something impossible to avoid in this model ${ }^{65}$. And although it is true that when this happens, it can cause some perplexity -but not constitute an authentic contradiction, because it is not convicting and acquitting the same person and for the same fact $^{66}-$, a clear explanation to society

63 Free translation.

64 CORDERO, Franco. Procedimiento penal, p. 305.

65 For example, see the judgments of the Viña del Mar Guarantee Court (Juzgado de garantia de Viña del Mar), of August 18, 2018, and of the Viña del Mar Court of Oral Criminal Trial (Tribunal de Juicio Oral en lo Penal de Viña del Mar), of January 15, 2021, both issued in the case RUC 1800167584 -9. The first sentence convicted one of the co-defendants in abbreviated procedure (procedimento abreviado) and the other acquitted another co-defendant in oral trial (juicio oral) for the same crime. In the same sense, see the judgments of the Copiapó Guarantee Court (Juzgado de garantia de Copiapó), of July 30, 2019, in abbreviated procedure (procedimento abreviado), and of the Copiapó Court of Oral Criminal Trial (Tribunal de Juicio Oral en lo Penal de Copiapó), in oral trial (juicio oral), in the case RUC 1900350243-3.

${ }^{66}$ In this sense, DE DIEGO DÍEZ, Luis-Alfredo. La conformidad del acusado, p. 347. 
that each process is different and the result of each trial depends on the evidence that is rendered could be enough to avoid such strangeness.

\section{Final Considerations}

It has been found in this work that when it comes to using negotiated criminal justice mechanisms in cases where there are codefendants, there are two theoretically applicable models: the consensual, which requires the agreement of all the defendants, and the individualist, which does not demand it and allows negotiation with some of the codefendants. It has also been found that both models have advantages and disadvantages and that both are observed in different Latin American criminal procedural legislations examined.

If it were decided to replace the individualist model with a consensual one in Chile, the conformity of all co-defendants should be required only when they are attributed participation in the same fact, in which some of the revised criminal procedural legislations can serve as an example. However, in this work it has been concluded that it is not convenient to adopt the consensual model in Chile, basically, because it could reduce the efficiency of the criminal procedure system of that country. But it has been also suggested that the decision to maintain the individualist model does not lose sight of the disadvantages of this model and the need of incorporate legal modifications that minimize the risk of attacks against the presumption of innocence of those codefendants who are not part of the agreement and who are brought to trial, in which some of the examinated procedural criminal legislations may also serve as an example. Likewise, seeking to mitigate the risk that equality before the law is violated, it has been suggested that a duty of the prosecutor be established to explain to the judge, at the time of approval of the agreement that is submitted for his consideration, the reasons why he has negotiated with some of the co-defendants and not with the others.

In summary, for the Chilean criminal procedural system, it seems preferable to keep the individualist model, but it would be advisable to make some legal modifications to correct some of its defects. 


\section{References}

ALBERGARIA, Pedro Soares de. Plea bargaining. Aproximação à Justiça Negociada nos E.U.A. Coimbra: Almedina, 2007.

ALSCHULER, Albert W. Plea bargaining and its history. Columbia Law Review, Nueva York, v. 79, n. 1, p. 1-43, 1979. https://doi.org/10.2307/1122051

ANITUA, Gabriel Ignacio. La importación de mecanismos consensuales del proceso estadounidense, en las reformas procesales latinoamericanas. Revista Brasileira de Direito Processual Penal, v. 1, n. 1, p. 43-65, 2015. https://dx.doi. org/10.22197/rbdpp.v1i1.3

BARONA VILAR, Silvia. La conformidad en el proceso penal. Valencia: Tirant lo Blanch, 1994.

BIBAS, Stephanos. Designing plea bargaining from the ground up: accuracy and fairness without trials as backstops. William and Mary Law Review, Virginia, v. 57, n. 4, p. 1055-1081, 2016.

CABEZUDO RODRÍGUEZ, Nicolás. El Ministerio Público y la justicia negociada en los Estados Unidos de Norteamérica. Granada: Comares, 1996.

CORDERO, Franco. Procedimiento penal, vol. II. Bogotá: Temis, 2000.

DA SILVA BRANDALISE, Rodrigo. Justiça Penal Negociada. Negociação de sentença criminal e princípios processuais relevantes. Curitiba: Juruá Editora, 2016.

DE DIEGO DÍEZ, Luis-Alfredo. La conformidad del acusado. Valencia: Tirant lo Blanch, 1997.

DEL RÍO FERRETTI, Carlos. Proceso penal, consenso de las partes y enjuiciamiento jurisdiccional. Santiago: Librotecnia, 2009.

DERVAN, Lucian E. and EDKINS, Vanessa A. The innocent defendant's dilemma: an innovative empirical study of plea bargaining's innocence problema. Journal of Criminal Law and Criminology, v. 103, n. 1, p. 1-48, 2013. https://doi.org/10.2139/ ssrn.2071397

DEVERS, Lindsey. Plea and Charge Bargaining: Research summary. Arlington: Bureau of Justice Assistance, U.S. Department of Justice, 2011.

DÍAZ PITA, María Paula. Conformidad, reconocimiento de hechos y pluralidad de imputados en el procedimiento abreviado. Valencia: Tirant lo Blanch, 2006.

DUCE JULIO, Mauricio. Los procedimientos abreviados y simplificados y el riesgo de condenas erróneas en Chile: resultados de una investigación empírica. Revista 
de Derecho de la Universidad Católica del Norte, vol. 26, p. 1-38, 2019. https://doi. org/10.22199/issn.0718-9753-2019-0012

GIACOMOLLI, Nereu José. Legalidad, oportunidad y consenso en el proceso penal. Lima: Ara Editores, 2012.

GROSSI, Ana Claudia. Pode o acordo ser uma solução para os problemas da morosidade e sobrecarga da Justiça? Subsídios para um debate, a partir da experiência alemã. Revista Brasileira de Ciências Criminais, Sao Paulo, v. 14, p. 133-171, 2015. https://doi.org/10.5585/rdb.v4i3.25

HERMOSILLA IRIARTE, Francisco. Valoración de las declaraciones de acusados y coimputados. Santiago: Librotecnia, 2019.

HERRERA GUERRERO, Mercedes. La negociación en el nuevo proceso penal: Un análisis comparado. Lima: Palestra Editores, 2014.

HORVITZ LENNON, María Inés and LÓPEZ MASLE, Julián. Derecho Procesal Penal Chileno, v. 2. Santiago: Editorial Jurídica de Chile, 2004.

LANGBEIN, John H. Torture and Plea Bargaining. The University of Chicago Law Review, v. 46, N. 1, p. 3-22, 1978. https://doi.org/10.2307/1599287

LANGER, Máximo. Plea bargaining, conviction without trial and the global administratization of criminal convictions. Annual Review of Criminology, California, n. 4, p. 1-35, 2021. https://doi.org/10.1146/annurev-criminol-032317-092255

LANGER, Máximo. From legal transplants to legal translations. The globalization of plea bargaining and the Americanization thesis in criminal procedure. In: THAMAN, Stephen C. (ed.). World Plea Bargaining. Consensual procedures and the avoidance of the Full Criminal Trial. North Carolina: Carolina Academic Press, 2010, p. 3-80.

LANGER, Máximo. Rethinking plea bargaining: the practice and reform of prosecutorial adjudication in American criminal procedure. American Journal of Criminal Law, Texas, v. 33, n. 3, 2006, p. 223-299.

LASCURAÍN SÁNCHEZ, Juan Antonio and GASCÓN INCHAUSTI, Fernando. ¿Por qué se conforman los inocentes? In Dret. Revista para el análisis del Derecho, n. 3, p. 1-28, 2018.

LOARCA, Carlos and BERTELOTTI, Mariano. El procedimiento abreviado en Guatemala. In: Maier, Julio and Bovino, Alberto (comp.). El procedimiento abreviado. Buenos Aires: Editores del Puerto, 2001, pp. 411-432. 
LOZANO EIROA, Marta. Conformidad y pluralidad de acusados. Revista de Derecho UNED, Madrid, n. 10, p. 347-365, 2012. https://doi.org/10.5944/ rduned.10.2012.11101

MAIER, Julio B. J. Prólogo. In: Maier, Julio and Bovino, Alberto (comp.). El procedimiento abreviado. Buenos Aires: Editores del Puerto, 2001, pp. I-III.

MALLORD, Joel. Putting plea bargaining on the record. University of Pennsylvania Law Review, Philadelphia, v. 162, p. 683-718, 2014.

MARTÍNEZ, Santiago. La víctima y el juicio abreviado. Buenos Aires: Fabián J. Di Plácido Editor, 2004.

MIRANDA ESTRAMPES, Manuel. La mínima actividad probatoria en el proceso penal. Barcelona: Bosch, 1997.

NÚÑEZ OJEDA, Raúl. Código Procesal Penal. Santiago: LegalPublishing - Thomson Reuters, 2014.

OLAIZOLA NOGALES, Inés. El principio de oportunidad. ¿Modernización o crisis del Derecho penal? Revista Nuevo Foro Penal, Medellín, v. 10, n. 82, p. 13-32, 2014. https://doi.org/10.17230/nfp.10.82.1

OLIVER CALDERÓN, Guillermo. Reflexiones sobre los mecanismos de justicia penal negociada en Chile. Revista Chilena de Derecho, Santiago, v. 46, n. 2, p. 451475, 2019. https://dx.doi.org/10.4067/S0718-34372019000200451

PECCHI CROCE, Carlos. El procedimiento abreviado en el nuevo Código Procesal Penal. Revista Actualidad Jurídica, Santiago, n. 11, p. 119-137, 2005.

PRADO, Geraldo. Transação penal, $2^{\mathrm{a}}$ ed. Rio de Janeiro: Editora Lumen Juris, 2006. PUENTE SEGURA, Leopoldo. La conformidad en el proceso penal español. Madrid: Editorial Colex, 1994.

RIED UNDURRAGA, Ignacio. El efecto de la sentencia condenatoria del procedimiento abreviado en el juicio indemnizatorio por responsabilidad civil ex delicto. Revista Ius et Praxis, año 23, n. 1, 2017, p. 579-626. https://dx.doi.org/10.4067/ S0718-00122017000100016

RIEGO RAMÍREZ, Cristián. El procedimiento abreviado en la ley 20.931. Política Criminal, v. 12, n. 24, p. 1085-1105, 2017. https://doi.org/10.4067/ s0718-33992017000201085

RIEGO RAMÍREZ, Cristián. La renuncia a las garantías del juicio oral por medio del procedimiento abreviado en Chile. Revista Brasileira de Direito Processual Penal, v. 3, n. 3, p. 825-847, 2017. https://doi.org/10.22197/rbdpp.v3i3.80 
RIEGO RAMÍREZ, Cristián. El procedimiento abreviado. In: Carocca Pérez, Alex et al. Nuevo proceso penal. Santiago: Conosur, 2000, p. 205-226.

RIVERA LEÓN, Mauro Arturo. Algunas consideraciones sobre el procedimiento abreviado. Revista Jurídica Online, Guayaquil, n. 26, p. 31-51, 2009.

RODRÍGUEZ GARCÍA, Nicolás. La justicia penal negociada: Experiencias de derecho comparado. Salamanca: Ediciones Universidad de Salamanca, 1997.

RODRÍGUEZ VEGA, Manuel. Discrecionalidad del Ministerio Público y objeto del juicio abreviado. Revista de Derecho de la Pontificia Universidad Católica de Valparaíso, Valparaíso, v. 36, p. 495-529, 2011. https://doi.org/10.4067/ s0718-68512011000100014

SCHÜNEMANN, Bernd. La reforma del proceso penal. Madrid: Dykinson, 2005.

SCHÜNEMANN, Bernd. ¿Crisis del procedimiento penal? ( 2 Marcha triunfal del procedimiento penal americano en el mundo?) In: The Same, Temas actuales y permanentes del Derecho penal después del milenio. Madrid: Tecnos, 2002, p. 288-302.

STIPPEL, Jörg and MARCHISIO, Adrián (coords.). Principio de oportunidad y salidas alternativas al juicio oral en América Latina. Buenos Aires: Editorial Ad-Hoc, 2002.

VASCONCELLOS, Vinicius Gomes de. As tendências de expansão da justiça criminal negocial em âmbito internacional: a barganha como instituto importado em convergências entre sistemas. Revista de Estudos Criminais, Porto Alegre, v. 19, n. 76, p. 153-173, 2020.

VASCONCELLOS, Vinicius Gomes de. Barganha e Justiça Criminal Negocial. Análise das tendencias de expansão dos espaços de consenso no proceso penal brasileiro. Sao Paulo: IBCCRIM, 2015.

ZAGMUTT VENEGAS, Valentina. Procedimiento abreviado y simplificado en la práctica de audiencias chilenas: ¿Alguna vinculación con la condena de inocentes? Santiago: Ediciones Jurídicas de Santiago, 2019. 


\section{Additional information and author's declarations (scientific integrity)}

Acknowledgement: The author thanks Claudia Perivancich Hoyuelos, Regional Prosecutor of the Public Ministry of Valparaíso (Chile), for her help in finding relevant statistical information for this work. He also thanks the anonymous reviewers for their valuable comments that helped improve the work.

Conflict of interest declaration: the author confirms that there are no conflicts of interest in conducting this research and writing this article.

Declaration of authorship: all and only researchers who comply the authorship requirements of this article are listed as authors; all coauthors are fully responsible for this work in its entirety.

Declaration of originality: the author assures that the text here published has not been previously published in any other resource and that future republication will only take place with the express indication of the reference of this original publication; he also attests that there is no third party plagiarism or self-plagiarism.

Editorial process dates

(http://www.ibraspp.com.br/revista/index.php/RBDPP/about/editorialPolicies)

- Submission: 25/02/2021

Editorial team

- Desk review and plagiarism check: 04/03/2021

- Editor-in-chief: 1 (VGV)

- Review 1: 29/03/2021

- Assistant-editor:1 (PMM)

- Review 2: 22/04/2021

- Reviewers: 3

- Review 3: 15/05/2021

- Preliminary editorial decision: $16 / 05 / 2021$

- Correction round return: 15/06/2021

- Final editorial decision: 19/06/2021 


\section{HOW TO CITE (ABNT BRAZIL):}

OLIVER, Guillermo. Convenience or inconvenience of requiring the unanimous consent of the co-defendants for the negotiated criminal justice mechanisms (in a restricted sense) in the Chilean criminal procedural system. Revista Brasileira de Direito Processual Penal, vol. 7, n. 2, p. 1261-1286, mai./ago. 2021. https://doi.org/10.22197/rbdpp.v7i2.532

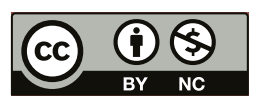

Esta obra está licenciada com uma Licença Creative Commons Atribuição-NãoComercial 4.0 Internacional. 